\section{National HIV Testing Day - June 27, 2018}

National HIV Testing Day, June 27, highlights the importance of testing in detecting, treating, and preventing human immunodeficiency virus (HIV) infection. Awareness of HIV infection through HIV testing is the first step to prevention, health care, and social services that improve life quality and length of survival (1).

Health care providers and others providing HIV testing can reduce HIV-related adverse health outcomes and risk for HIV transmission by implementing routine and targeted testing to decrease diagnosis delays (2). In this issue, an analysis of national population-based survey data collected during 2006-2016 found that persons with higher risk for HIV in the past year did not achieve CDC's recommended frequency of at least annual screening and the median time between tests did not change (3). Health care providers and public health practitioners need to intensify efforts to routinely screen all patients for HIV infection, and to identify persons with ongoing risk and ensure that they are engaged in annual screening for HIV infection.

Additional information on National HIVTesting Day is available at https://www.cdc.gov/features/HIVtesting. Basic testing information for the public is available at https:// www.cdc.gov/hiv/basics/testing.html. Additional information on HIV testing for health professionals is available at https://www.cdc.gov/hiv/testing. CDC's guidelines for HIV testing of serum and plasma specimens are available at https://www.cdc.gov/hiv/guidelines/testing.html.

\section{References}

1. Bradley H, Hall HI, Wolitski RJ, et al. Vital signs: HIV diagnosis, care, and treatment among persons living with HIV-United States, 2011. MMWR Morb Mortal Wkly Rep 2014;63:1113-7.

2. Dailey AF, Hoots BE, Hall HI, et al. Vital signs: human immunodeficiency virus testing and diagnosis delays_-United States, 2017. MMWR Morb Mortal Wkly Rep 2017;66:1300-6. https:// doi.org/10.15585/mmwr.mm6647e1

3. Pitasi MA, Delaney KP, Oraka E, et al. Time since last HIV test for men and women with recent risk for HIV infection-United States 2006-2016. MMWR Morb Mortal Wkly Rep 2018;67:677-81.

\section{Interval Since Last HIV Test for Men and Women with Recent Risk for HIV Infection - United States, 2006-2016}

Marc A. Pitasi, $\mathrm{MPH}^{1}$; Kevin P. Delaney, $\mathrm{PhD}^{1}$; Emeka Oraka, $\mathrm{MPH}^{2}$; Heather Bradley, $\mathrm{PhD}^{1}$; Elizabeth A. DiNenno, $\mathrm{PhD}^{1}$; John T. Brooks, $\mathrm{MD}^{1}$; Joseph Prejean, $\mathrm{PhD}^{1}$

Since 2006, CDC has recommended routine screening of all persons aged 13-64 years for human immunodeficiency virus (HIV) and at least annual rescreening of persons at higher risk (1). However, national surveillance data indicate that many persons at higher risk for HIV infection are not screened annually, and delays in diagnosis persist (2). CDC analyzed 2006-2016 data from the General Social Survey (GSS)* and estimated that only $39.6 \%$ of noninstitutionalized U.S. adults had ever tested for HIV. Among persons ever tested, the estimated median interval since last test was 1,080 days or almost 3 years. Only $62.2 \%$ of persons who reported HIV-related risk behaviors in the past 12 months were ever tested for HIV, and the median

* Conducted by the National Opinion Research Center at the University of Chicago. http://www.gss.norc.org/.

\section{INSIDE}

682 Self-Reported Concussions from Playing a Sport or Being Physically Active Among High School Students - United States, 2017

686 Smoke-Free and Tobacco-Free Policies in Colleges and Universities — United States and Territories, 2017

690 Strategic Response to an Outbreak of Circulating Vaccine-Derived Poliovirus Type 2 - Syria, 2017-2018

696 QuickStats

Continuing Education examination available at https://www.cdc.gov/mmwr/cme/conted_info.html\#weekly.



U.S. Department of Health and Human Services Centers for Disease Control and Prevention 